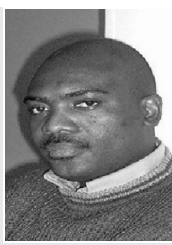

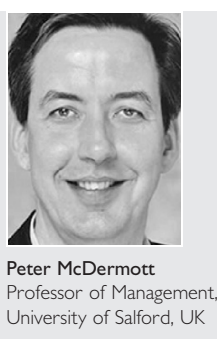
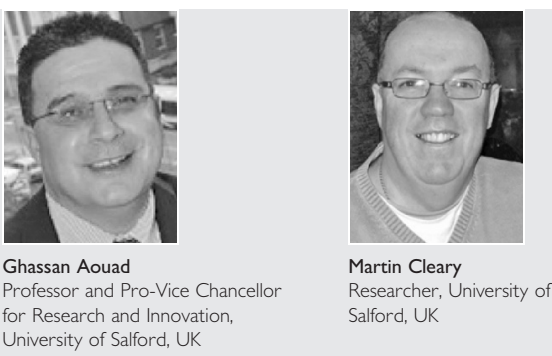

\title{
Skill competency development strategies by a contractor
}

A. S. Oyegoke HND, MSc (Tech.), Lic. Sc. (Tech.), DSc, MACostE, MCIOB, P. McDermott MSc, PhD, G. Aouad MSc, PhD, FCIOB, FHEA and M. Cleary BA, PGCE

Construction skill is one of the vital aspects of construction work which is growing in importance due to skill gaps and skill shortages during different economic cycles. The aim of this study was to investigate competence development strategies by a traditional construction company within its own pool of skill resources and among its supply chain members. The study was carried out via literature review, empirical studies involving a focus study, analysis of documentary evidence supported by unstructured interviews and a report of skill development/supply chain conference. The study demonstrates how longterm skill development can be achieved through: (a) strategic capacity planning which allows high retention, continuous training, and balanced construction demand and contractor's supply capacity over a long-term; (b) updating and upgrading the knowledge base of the supply chain through conferences and training schemes; (c) strategic investment in the workforce through training, vocational and higher degrees; and (d) acquaintance with different sources of finance. This study will assist small traditional firms in building competencies in skill development and improvement. It will assist an international audience who may face similar issue with their construction firms.

\section{INTRODUCTION}

Construction, as in other production processes, involves a process of transforming inputs into outputs by using necessary resources. These resources are accumulated stocks of means of production and overall productivity performance. Skills have been one of the most important issues in the construction industry due to the fact that the construction methods are largely primitive; hence the necessity of a labour-intensive workforce. The fact that the structure of the industry is highly fragmented entails the need for many different skill sets.

There are a number of factors that are attributed to skills shortage, the foremost being the impact of demand and supply interaction through construction demand and supply side capacity constraints, ${ }^{1}$ the effect of new technologies, ${ }^{2}$ demographic issues and lack of interest by young people, ${ }^{3}$ issues related to training resources, ${ }^{4}$ and the effects of market cycles, namely the cyclical nature of the industry market. ${ }^{5}$
The skill problem is compounded in the UK due to a lack of investment during the recession in the late 1980s and early 1990 s. Blyth refers to this period as ${ }^{6}$ 'the Brain Drain' and a sequence of events which led to significant shortages in human resources. He emphasises ${ }^{6}$ that, 'during that time the industry stopped taking on new graduates, those who had recently graduated from buildingrelated courses were unable to find work, universities axed construction courses and the construction industry suffered greatly and stopped recruiting'. According to Mackenzie et al. the effects ${ }^{7}$ were seen during the economic recovery with considerable skills shortages in both traditional and new skills areas.

There are three dynamics in developing construction skill competencies: first, an attainment of equilibrium between construction demand and supply capacities. On construction demand and supply capacity issues the government commissioned a study to improve long-term capacity planning. ${ }^{8}$ The report recommended among other things the need to take a much more systematic and strategic approach to the markets in which it operates. Second, building competencies to address skills shortages, which are a result of the imbalance between demand and supply of workforce, and third, addressing the skill gaps which occur as a result of knowledge deficiencies that might be due to new construction materials, means, techniques and technology.

On skills shortages and skill gaps the ConstructionSkills ${ }^{9}$ negotiated a series of agreements between training providers, employers and government that were designed to address the construction industry's current and future skills needs. According to the ConstructionSkills, ${ }^{9}$ this agreement significantly increased employer commitments to training and skills in partnership with further and higher education and government agencies. In addition to considerable investment by individual companies employers have agreed a financial strategy in which they will provide funding of over $£ 120$ million per year for collective training activity.

Construction skills have been a recurring and topical issue because of the cyclical nature of the market. Huemann et al. ${ }^{10}$ viewed human resource management as a core process of the projectoriented company affecting the way the organisation acquires and uses human resources and how employees experience the employment relationship. Different issues surrounding 
construction skills have been addressed by many authors: skill training in relation to business processes $;{ }^{11}$ operative training; ${ }^{12}$ the UK vocational training policy; ${ }^{13}$ and the contribution of National Vocational Qualifications (NVQ) to the growth of skills in the UK. ${ }^{14}$ It also includes the decline of apprenticeship training in Britain $;{ }^{15}$ relationships between training and turnover; ${ }^{16}$ formulation of common training policy in the context of European development; ${ }^{17}$ and apprenticeship training. ${ }^{18}$

Other studies have looked at the developing project management competency $;^{19}$ project management practitioner development; ${ }^{20}$ skills in terms of self employment; ${ }^{21}$ the importance of human skills in project management success; ${ }^{22}$ the importance of 'soft' skills or 'micro-social' skills in successful project management; ${ }^{23}$ project workforce management; ${ }^{24}$ and skills in relation to productivity. ${ }^{25}$ Pheng and Chuan examined the area of improving a project manager's performance ${ }^{26}$ by identifying the working environment variables which affect his performance. Lobo and Wilkinson assess solutions to skills shortages in the construction industry ${ }^{27}$ drawing on research from New Zealand. They suggested ${ }^{27}$ increase in wages, overseas recruitment and reformatting training requirements through a joint focus on education and training. Mackenzie et al. ${ }^{7}$ describe seven existing industry and government schemes that helped in tackling skills shortages, and a further nine alternative response strategies to the construction skills shortage.

The aim of this paper was to present skill competency strategies by a small traditional contractor. The paper describes how some of the government and industry initiatives have been successfully implemented in addition to the contractor's own initiatives. The study looked at the period when the demand capacity was at its highest in the UK between 2002 and the first and second quarter of 2008.

\section{RESEARCH METHODS}

The study was carried out via literature review and empirical studies involving a focus study, data analysis from construction statistics, analysis of documentary evidence with unstructured interviews, and a skill development/supply chain conference. A focus group study was carried out as a preliminary study aimed at understanding the most pressing issues in skill development and improvement. Although the causes of the skill shortage in the UK construction industry are well documented, this focus group study approach enabled the authors to discover the most pressing issues and to know how far the industry has moved on from some of the problems in the literature.

The attendees were part of the North West (NW) ConstructionSkills Observatory meeting. There was a balanced distribution of participants from young professional to experienced practitioners and highly experienced retired people. There were sixteen participants, nine from a contracting background, four from a consulting background and three from academia. The participants came from different backgrounds having worked or currently working for specialist trade contractors, main contractors, developers, consulting firms and in academia.

The group was asked about their experiences and the problems in skill development and improvement in the UK. The issues dealt with in a $90 \mathrm{~min}$ meeting/study can be categorised under: $(a)$ skills finances, (b) training standards and (c) general issues.

\section{I. Financing: funding in skill sets}

(a) Funding is said to be a major impediment to skill development. The small specialist trade firms are not aware of funding sources and/or capable of self funding. A good example is the ConstructionSkills Certification Scheme (CSCS) which was problematic due to training time and funding.

(b) Self financing for the large companies and greater flexibility in releasing employees for training.

(c) Contractor's cash flow inhibits training of the workforce, most especially the small medium enterprises (SMEs).

(d) Extra labour costs due to the delay caused by unforeseen circumstances, for example, archaeological findings on the site.

\subsection{Training standards}

(a) Qualification criteria in higher institutions.

(b) Training standards in vocational institutions/apprenticeship.

(c) Old skills versus new skill sets; for example, the use of formwork is plummeting and in time will not be critical in construction.

(d) Skill shortage across the board at both management and operative levels.

(e) The industry needs quick qualification and learning from overseas; for example, the prefabrication systems in Finland and Scandinavia.

(f) Education reform: changing perceptions of young people's view of the industry.

$(g)$ Diversity of the industry - with diversified opinion.

\subsection{General effects}

(a) Technological effects, for example, in plumbing where new technology is been developed.

(b) Effects of the developers are paramount.

(c) Effects of highly specialised skills versus multi-skills.

(d) Effects of the modern construction or offsite manufacturing.

(e) Data-sharing problems.

(f) Effects of a huge number of interventions, for example, health and safety, levies, sustainability.

(g) The influence of the movers and shakers of the industry, such as town planning authorities and how their decisions shape the future. A good example is the planner instruction SSG 304 in which maximum use of the land is advocated in order to eliminate parking on a share or limited basis. But now those properties cannot be sold due to demand for parking space.

(h) Retirements: useful and valuable knowledge is lost in retirement. It could have served as a useful means of improving skills. The opportunities for the retiree to come out of retirement is hampered by low incentives even when such positions are available.

(j) The effects of the black economy, for example, about 25000 gas workers are assumed not to be registered.

From the focus study it was found that some of the problems identified and government response strategies highlighted by Mackenzie et al. are still prevalent today. ${ }^{7}$ For instance, issues about new technology and techniques, economic stability within the industry, effects on direct employment, adult training and other problems associated with training.

Having identified these problems, a study of a small-size contractor was conducted in order to understand how these 
problems have been managed. The study was based in part on documentary evidence that was used to win a gold certificate under the CSCS scheme, other human resources documentary evidence and unstructured interviews, and participation in a supply chain conference.

\section{DYNAMICS IN THE UK CONSTRUCTION INDUSTRY}

One of the causes of the skills shortage in the UK construction industry is the changing nature of construction markets and the demand capacity problem which has been attributed to a higher demand for operatives with many traditional skills. At the peak of the demand capacity problem in 2006, the government of the UK through the Office of Government Commerce (OGC) ${ }^{1}$ commissioned a study of the demand capacity problem. This section will examine the dynamics in the demand and supply side of the construction industry through construction statistical data.

\section{I. Dynamics in the demand side of the industry}

The UK construction industry is heavily invested in by the public and private sectors. The Construction Statistic data by the Office for National Statistics ${ }^{28}$ shows that about $£ 6.88$ billion, $£ 19.81$ billion, $£ 15.12$ billion and $£ 16.04$ billion were the combined new orders by both private and public in housing sector in 1999, 2003, 2005 and 2007, respectively. The increment in investment extends to the new order for infrastructure which amounted to about $£ 4 \cdot 12$ billion, $£ 4.89$ billion, $£ 5.53$ billion and $£ 5.63$ billion as well as in the non-housing sector (excluding infrastructure) which amounted to about £15.02 billion, £18.26 billion, $£ 23.28$ billion and £28.92 billion in 1999, 2003, 2005 and 2007, respectively.

Figure 1 presents the analysis of the gross fixed capital formation at 2008 purchaser's prices for the total economy under public and private sectors. The trap-like shape of the figure shows the rise in the government commitment in spending by narrowing the gap in capital formation by the private and public sectors. The increase in public and private investment, the pressure to attain a decent level of sustainability, the sizeable amount of renovation and maintenance work, and the relatively slow but steadily increase in the practice of new methods of construction have triggered higher demand for different levels of skills.

\subsection{Government response/intervention to demand capacity issues}

On the demand side, there has been a robust government strategy to intervene and aggregate public construction demand through framework agreements. The pattern of government investment, which has been increasing since year 2000 with a nominal increase on the supply side, calls for an intervention strategy to pool government requirements together for fewer and larger contracts. The method of pooling demand and supply requirements together is known as aggregation. On the demand side is the coordination of project requirements and on the supply side is the consolidation of supply in response to the ways the demand is placed in the market. The OGC report on aggregation states $^{29}$ that the decision to use aggregation should be made during the development of organisational procurement strategies and during strategic planning stage prior to a programme or project. The OGC report advocates ${ }^{8}$ a stronger lead from the centre and a professional approach to business planning, programme/ project management and procurement.

A demand aggregation decision involves three important steps according to the OGC report ${ }^{29}$

(a) Providing management information through trends analysis of purchasing trends.

(b) Providing information on the future common or similar requirements within or between organisations.

(c) Assessing the potentials in combining or collaborating within and between organisations.

When the combinations of requirements include diverse but related requirements it is referred to as bundling.

\subsection{Dynamics in supply side of the industry}

The supply side of the UK construction industry is fragmented both from the consulting and contracting point of view. Cox and Ireland suggest ${ }^{30}$ there exist a range of supplier's relationships ranging from a purely independent transactional, price-based interaction to highly interdependent relationships and then to a dependent sourcing arrangement. In consulting practice, different firms across different disciplines are represented by different professional bodies and these firms engage in different tasks and activities. For instance, the survey of UK construction professionals undertaken in 2001/2002 shows ${ }^{31}$ that there were 8882 architectural firms, 6309 civil and structural engineering firms, 1875 building services engineering firms, 1871 quantity

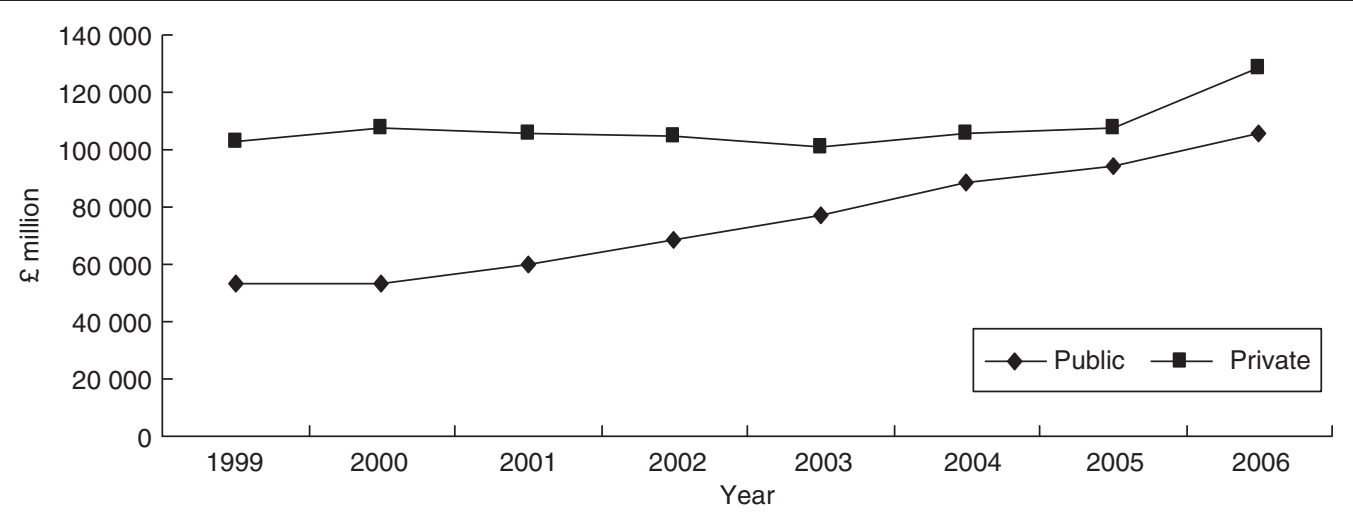

Figure I. Investment by private corporations and public entities. Source: Construction Statistics Annual ${ }^{28}$ 
surveyors firms, 1558 other surveyors firms, 722 firms for managers and 2293 other firms (including planners). Each of these disciplines has a range of specialisations resulting in a further fragmentation of the professional supply chain. In 2001/2002, the industry employed about 225000 people with estimated income of about $£ 12 \cdot 3$ billion in fee income.

The structure of the industry indicates a high level of collaboration as the number of firms under main trade (general builders, building and civil engineering contractors, non-residential building, housing and civil engineering) declined in number whereas specialist trades increased in number as shown in Figure 2. The number of main trades decline by 33\% from 60858 in 1999 to 45706 in 2005 whereas the number of specialist trades surged by 39\% from 104703 in 1999 to 145792 firms in 2007.

The influence of specialist trades in UK construction industry has been immense as shown in Figure 3. The value of work done by both main and specialist trades increased due to the economic boom. The share of specialist trades rose by $46 \%$ in 1999 to $51 \%$ in 2005. The main trades have seen a $£ 744$ million average growth between 1999 and 2007 and specialist trades grew by average of £961 million between the same years.

Table 1 compares the percentage share of number of firms and their value of work done. This categorisation is based on the number of employees in accordance with the construction statistical data. From 1999 to 2007, the number of firms in the small-scale firms (SSFs) category decreased by $2.5 \%$ and the value of work done in this category slumped by 15\%. In the mediumscale firms (MSFs) category, the number of firms increased by $2 \cdot 4 \%$ and the value of work done in this category increased by $5 \cdot 8 \%$. The large-scale firms (LSFs) category showed an increase in the number of firms by $0 \cdot 20 \%$ and in value of work done by 9.3\% between 1999 and 2007. There are two implications of this analysis: $(a)$ the specialists are actively engaged; and $(b)$ the specialist engagement is in the form of a collaborative arrangement under subcontracting arrangements. This assertion is supported by ConstructionSkills, ${ }^{9}$ which emphasises that the construction industry is seeing a growth in demand for specialist trades throughout the supply chain in both new build and in repair and refurbishment.

The upper part of Table 1 is the percentage share of the number of firms along three business classifications based on the number of employees in accordance with the categorisation in the construction statistical data. The lower part consists of value of work done in each of the categories between 1999 and 2007.

It is evident from the demand and supply chain data that the construction market in the UK had capacity problems until the third quarter of 2008. On the demand side is the increasing capacity due to the surge in the workload across both private and public sectors. The supply chain data indicates the surge in the number of specialist firms due to the risk transfer mechanism by larger firms to the smaller firms. Morton and Jaggar argued in favour of alternative strategy of direct employment ${ }^{32}$ to promote commitment and improve workers efficiency. Mackenzie et al. emphasise $^{7}$ that the growth in labour-only subcontracting and self-employment has led to a decline in training.

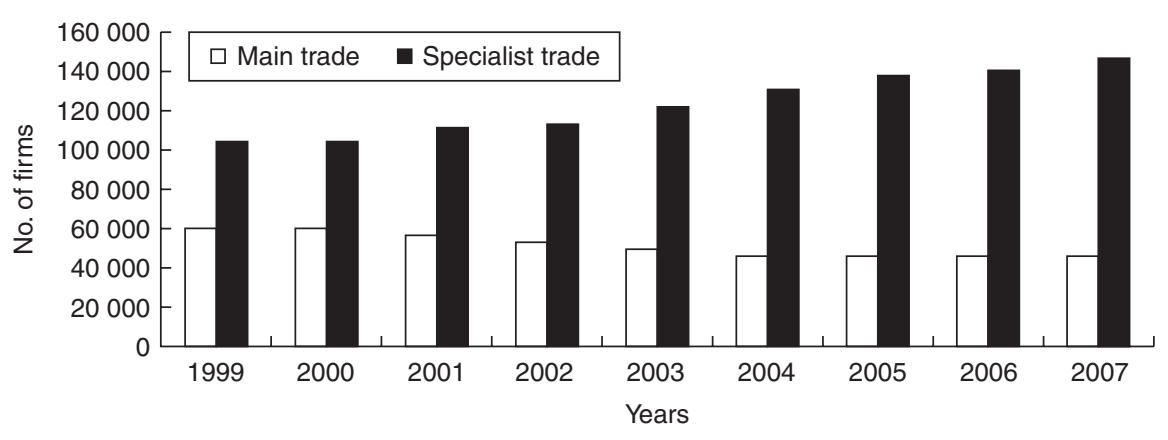

Figure 2. Comparison of the value of work done by main and specialist trades in UK (1999-2005). Source: Construction Statistics Annual ${ }^{28}$

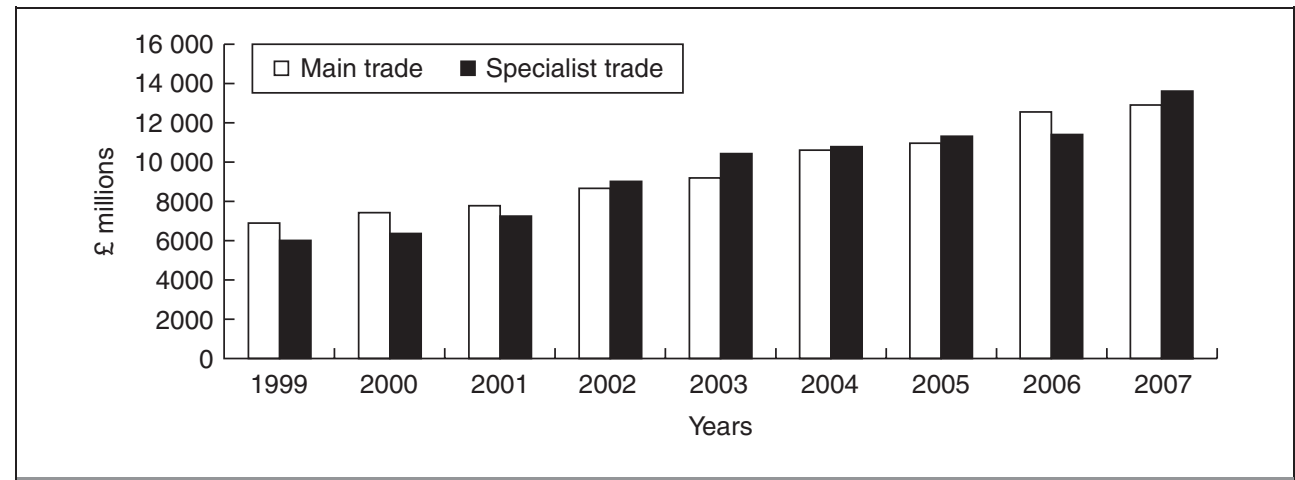

Figure 3. Comparison of number of main and specialist trades in UK (1999-2007). Source: Construction Statistics Annual ${ }^{28}$

\section{SKILLED AND UNSKILLED LABOUR}

The balance between the level of the required category of labour and the amount required to successfully execute the projects in a given year will show the trends in skills. This section brings together analysis from demand and supply sides of economy to analysis skill trends in the industry. This will be based on the unfilled demand on the demand side and lack of relevant skills in the market. In a nutshell, the skills shortages relate to a shortage of individuals with the required skills in the external labour market. This problem is unnecessarily compounded because of the skill gaps which indicate deficiencies in the skills of the current workforce and the sizeable number of craft-based occupations (plumber, electricians, etc.) which are for domestic and maintenance works. 


\begin{tabular}{|c|c|c|c|c|c|c|c|c|c|c|}
\hline Categories & $\begin{array}{c}\text { No. of } \\
\text { employees }\end{array}$ & 1999 & 2000 & 2001 & 2002 & 2003 & 2004 & 2005 & 2006 & 2007 \\
\hline \multicolumn{11}{|c|}{ Number of firms } \\
\hline SSFs $n$ & $1-13$ & $95 \cdot 7 \%$ & $96.0 \%$ & $94 \cdot 6 \%$ & $93 \cdot 6 \%$ & $93 \cdot 3 \%$ & $93 \cdot 3 \%$ & $93 \cdot 3 \%$ & $93 \cdot 2 \%$ & $93.2 \%$ \\
\hline MSFs $n$ & $14-79$ & $3.7 \%$ & $3.5 \%$ & $4.8 \%$ & $5.7 \%$ & $6.0 \%$ & $6.0 \%$ & $6.0 \%$ & $6.1 \%$ & $6.1 \%$ \\
\hline LSFs $n$ & $80-1200+$ & $0.5 \%$ & $0.5 \%$ & $0.6 \%$ & $0.7 \%$ & $0.7 \%$ & $0.7 \%$ & $0.7 \%$ & $0.7 \%$ & $0.7 \%$ \\
\hline Total & & $100.0 \%$ & $100 \cdot 0 \%$ & $100 \cdot 0 \%$ & $100 \cdot 0 \%$ & $100 \cdot 0 \%$ & $100 \cdot 0 \%$ & $100 \cdot 0 \%$ & $100.0 \%$ & $100 \cdot 0 \%$ \\
\hline \multicolumn{11}{|c|}{ Value of work done } \\
\hline SSFs $v$ & $1-13$ & $34.4 \%$ & $36.4 \%$ & $33.0 \%$ & $20 \cdot 0 \%$ & $24.0 \%$ & $20 \cdot 0 \%$ & $20 \cdot 8 \%$ & $19.9 \%$ & $19.4 \%$ \\
\hline MSFs $i$ & $14-79$ & $22 \cdot 4 \%$ & $23.9 \%$ & $23 \cdot 8 \%$ & $28 \cdot 4 \%$ & $25 \cdot 7 \%$ & $27 \cdot 0 \%$ & $26.4 \%$ & $26 \cdot 4 \%$ & $28.1 \%$ \\
\hline LSFs $v$ & $80-1200+$ & $43 \cdot 2 \%$ & $39.7 \%$ & $43 \cdot 2 \%$ & $51.7 \%$ & $50 \cdot 6 \%$ & $53 \cdot 2 \%$ & $52.9 \%$ & $53.7 \%$ & $52.5 \%$ \\
\hline Total & & $100.0 \%$ & $100.0 \%$ & $100 \cdot 0 \%$ & $100 \cdot 1 \%$ & $100 \cdot 3 \%$ & $100 \cdot 2 \%$ & $100.0 \%$ & $100.0 \%$ & $100.0 \%$ \\
\hline
\end{tabular}

The construction statistical data reveal ${ }^{28}$ the growth in construction specialist trades between 1999 and 2005. For instance, the number of scaffolding firms grew by $40 \%$, installation of electrical wiring and fitting firms by $28 \%$, joinery installation by $81 \%$, and roofing firms have grown in number from 5636 to 7086 which represents a 26\% increase. However, the number of painting firms has reduced from 8921 in 1999 to 7621 in 2005 and the plant hire firms were reduced by $27 \%$. The underlying reason for this mixed signal the boom in the market which leads to an increase in the number of the firms and the shortages of required skill workers (crafts).

The ConstructionSkills report, The Blueprint for UK Construction Skill 2006-2010 forecasts ${ }^{33}$ that 348000 more employees will be needed for the construction industry by 2010 to meet expected demand, amounting to an average of 87000 new recruits per year. The requirement for skilled craft/trade specialist cuts across all trades. On the top of this predicted future average requirement of employees are those in wood trades 11090 , electricians 8130 , plumbers 5330, bricklayers 4730, etc. On the administrative and managerial side there is an average requirement of 10530 managers, 8610 clerical staff, 4790 engineering, information technology (IT) and other professionals and 3260 technical staff.
The ConstructionSkills report ${ }^{33}$ paints a grim picture of how site workers enter the industry through informal routes, learn on the job and have no formal qualifications. It is estimated that 500000 workers do not have qualifications at Vocational Qualification Level 2 or equivalent. Ruiz ${ }^{35}$ claims that there is no clear evidence of whether skills shortages in construction and metal trades may be long term and linked to the structural change in the economy, or short term and linked to the economic business cycle.

Figure 4 presents a measure of the notional trend of costs to contractors by comparing the changes in the cost of labour, materials and plant by application of the Price Adjustment Formulae for Building and Specialist Engineering Works for housing and non-housing. The notional trends for the costs of labour and plant for housing and non-housing have the same incremental costs with over 48\% growth 1999 to 2005. In the same period of time the material cost increased just by 23 and 18\% in non-housing and housing sectors, respectively. There was a growth in manpower of over $26 \%$ in the same period. The implication is that supply did not meet the demand in both labour and plant which resulted in extra costs to contractors.

Figure 5 presents the yearly percentage difference of investment and the number of the manpower. The lack of investment in
The CIOB survey 2006 on skills shortages $^{34}$ in the UK construction industry reported on a significant skills shortages. The OGC construction demand/supply capacity report ${ }^{1}$ attested to the fact that there are some skills gaps in certain trades and significant skills shortages in specific professional disciplines; leadership, project management and specific

Q2 aspect of design (e.g. MAtE design). It supports the assertion above that management and craft levels are one of the areas in which skill shortages are pronounced. The influx of migrant workers has not filled the skill gap. ${ }^{34}$

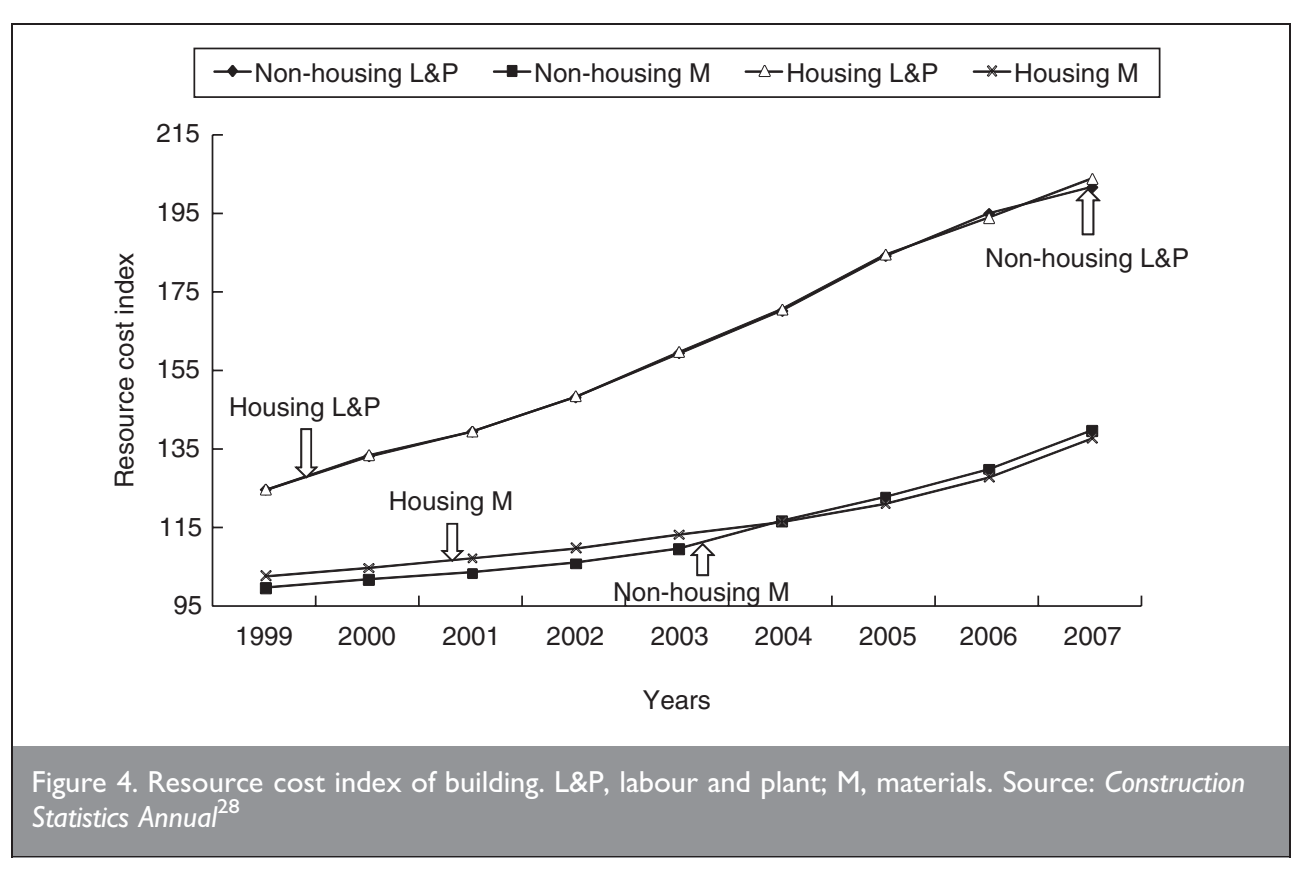




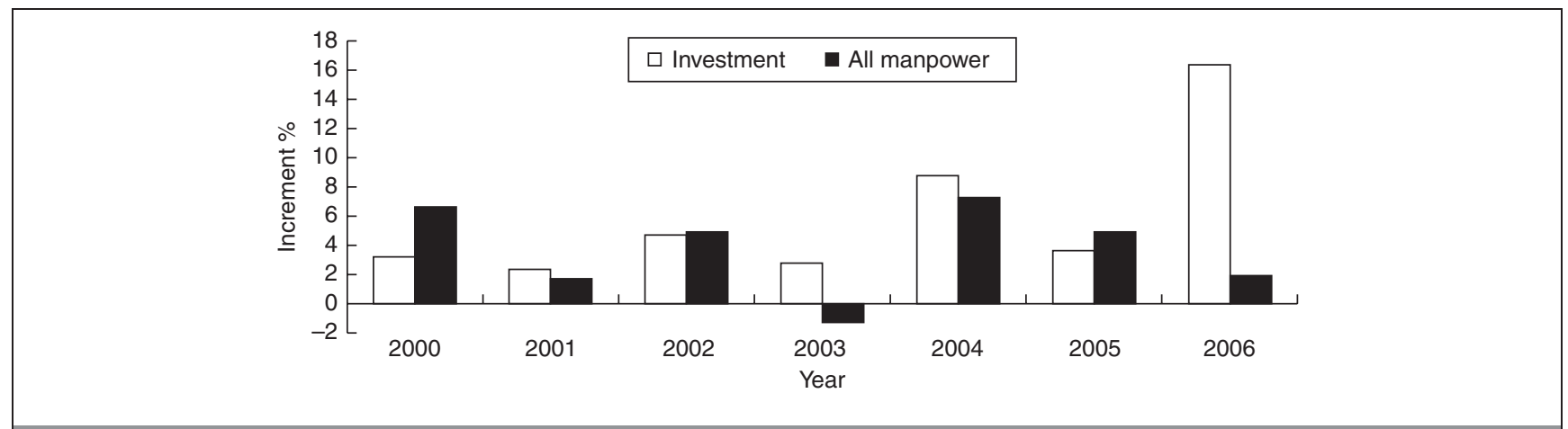

Figure 5. The yearly percentage difference in the amount of investment and number of manpower from 1999 to 2006. Source: Construction Statistics Annual ${ }^{28}$

construction skills during the recession in the late 1980s and early 1990s is reversed. This is due in part to a number of initiatives introduced by the ConstructionSkills and the influx of foreign workers which contributed to an increase to the workforce in general. The amount of investment grew in 2003 and the number of manpower deepened due in part to the return of some foreign workers. The yearly difference of the amount of investment and number of manpower substantially increased in 2004 and 2006 when compared with 2003 and 2005, respectively.

\section{CASE STUDY}

\section{I. Introduction}

The case company undertakes general contracting work for the public and private sectors, together with its own property development work. The company became an investor in people in December 2001 and won a CSCS gold certificate in 2008. All the company's sites are registered under the Considerate Construction Scheme and follow the scheme's eight-point codes under the three code areas: the environment, the workplace and the general public. The company focuses on the general skill development and improvement of the all employees at different levels in the business, in terms of investment and quality.

\subsection{Strategic capacity planning}

The company prefers to follows its strategic plans rather than opportunistic jobs. The company has a 5-year short-term plan and a 15-year long-term plan. Even during the boom period, the company avoids the temptation to become involved in many opportunistic jobs. The underlying philosophy is strategic capacity planning which is focused on manageable growth and workforce retention which is about 90\%. 'Partnered or repeated clients' work makes up approximately 50\% of turnover and the company has seen significant levels of organic growth over the past 5 years from £8.4 million in 2002 to £31 million in 2007.

Their strategic plan is to increase their turnover to around $£ 41$ million and $£ 44$ million in 2008 and 2009, respectively, with prospective monthly turnover of £3.67 million. The company’s ethos is to have a realistic strategic plan that will enable it to have a higher retention rate among its workforce and long-term training and improvement. The company focuses on client satisfaction, organic growth, business success, repeat client and investment in people. The nature of their procurement activities follows tendered, negotiation and partnering. The company belongs to three frameworks already and sees partnering and collaboration working arrangements as the future trend in the company.

\subsection{The nature of training}

The company training arrangement over a 5-year period can be categorised into three as shown in Figure 6: further education courses and NVQs; health and safety and technical issues; and management, general, IT and continuing professional

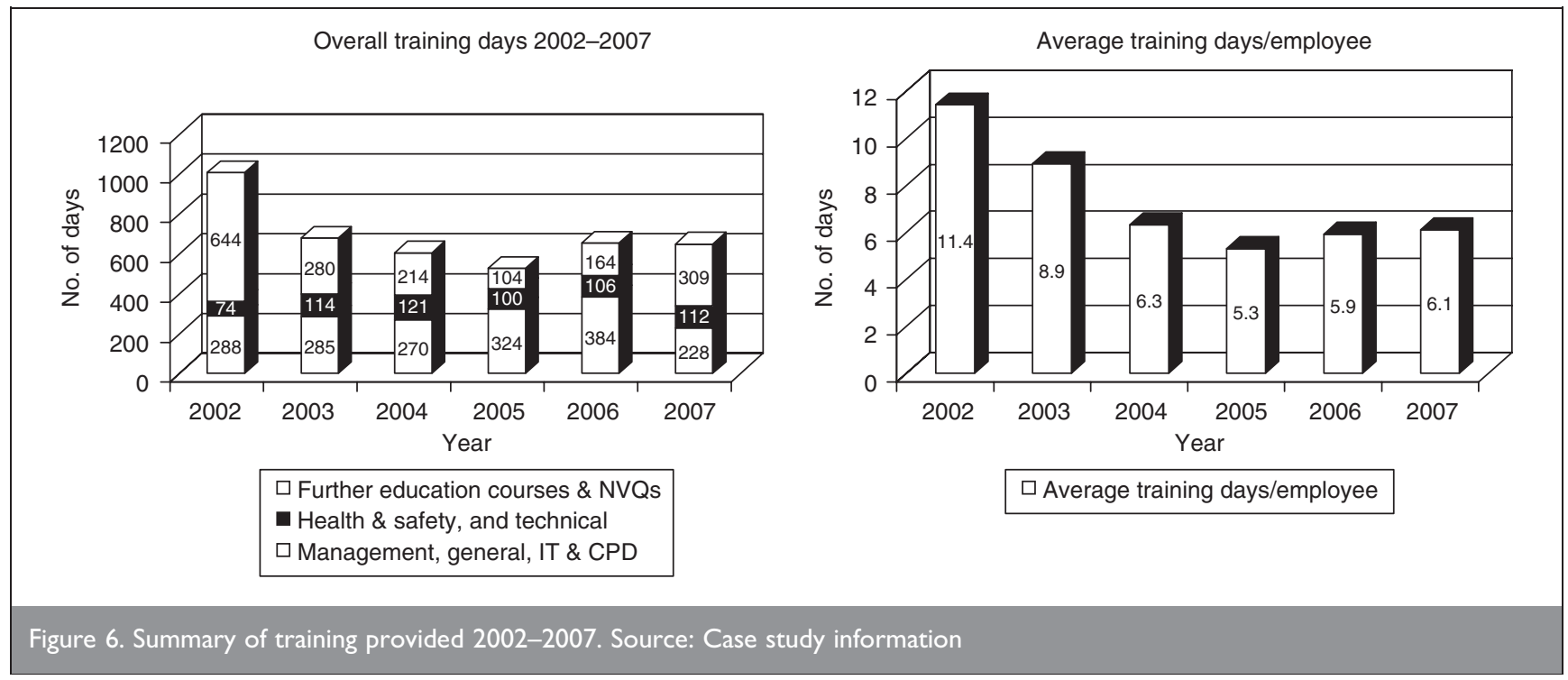




\begin{tabular}{|c|c|c|c|c|c|c|}
\hline Year & $\begin{array}{l}\text { No. of new } \\
\text { apprentices }\end{array}$ & Type & NVQ II & NVQ III & HNC & $\begin{array}{c}\text { Foundation } \\
\text { degree }\end{array}$ \\
\hline 2001 & 2 & 2 joiners & & 2 & $\mathrm{I}^{\dagger}$ & \\
\hline 2002 & 4 & $\begin{array}{l}3 \text { joiners } \\
\text { I bricklayer }\end{array}$ & 3 & & & \\
\hline 2003 & 2 & 2 joiners & & 2 & & \\
\hline 2004 & $5^{*}$ & $\begin{array}{l}4 \text { joiners } \\
\text { I bricklayer }\end{array}$ & 3 & I & & \\
\hline 2005 & 3 & $\begin{array}{l}2 \text { joiners } \\
\text { I bricklayer }\end{array}$ & 3 & I & & \\
\hline 2006 & 0 & Insufficient ex & d mentors & to support & take & \\
\hline 2007 & 4 & 4 joiners & & & 1 & \\
\hline
\end{tabular}

development. A high retention rate among their workers, a rigorous employment policy and a buoyant construction market resulted in lower average training days per employee, dropping from $11 \cdot 4$ days/employee in 2002 to $5 \cdot 3$ days in 2004 and a slight rise to $6 \cdot 1$ days in 2007 .

The nature of the training covers sustainable issues, health and safety, contractual issues, skill training, and business

development and improvement. Table 2 also indicates that all the employees both in construction and administration are eligible for the training activities. In recent time, supply-chain subcontractors are also now being included in training provision. 14\% of the sitebased workforce are apprentices (company target $=10 \%$ ) and the company has developed a reputation for the quality of its apprentice training and support. The company's ethos is very much 'train to retain'. In addition the company apprentice training provides for a 4-year training period including one or two years spent as 'improvers' to help newly-qualified apprentices in order to improve quality and productivity in a supportive environment.

Support provided to all apprentices includes

(a) thorough induction and health and safety training

(b) provision of tools

(c) assistance with transport

(d) nominated 'mentor' to help with learning and development

(e) regular meetings and reviews

(f) study leave, if necessary to help revise and pass exams

$(g)$ inclusion in other training initiatives being offered to the workforce, e.g. operator training (where appropriate)

(h) inclusion in employee 'away days' and discussion groups

$(j)$ in some case, assistance with financial difficulties

(k) general support.

The company operates 4-year training schemes in site joinery,

Q3 bench joinery and bricklaying. The first 2 or 3 years* is spent undertaking day-release courses. In the third and fourth years, as appropriate, the apprentices are viewed as 'improvers' in order to assist them to hone their skills, gain more experience and improve their productivity in a supportive environment. To date, the company has achieved a 90\% retention rate following completion of the scheme and two joiners are now studying further education courses with a view to progressing to trainee site managers in the future.
The company is not only receiving training but also disseminates its competence in building in skills to other companies. The human resources (HR) director is regularly invited by ConstructionSkills to present at training sessions for other small and medium construction companies with regard to topics such as: the benefits of implementing the Investors in People Standard and designing and introducing performance review systems. In addition, the HR director actively participates in the Best Practice Club. This assists the company to keep abreast with the opportunity for funding.

The document provided by the company shows that in 2008, over 250 days of training have taken place. This precludes some training under the ConstructionSkills Training Plan route to funding for internal training, for example, inductions and tool box talks, etc. This figure also excludes training days related to day-release for employees who attend college on a day-release basis (seven people in total), or those who attend courses in the evenings.

\subsection{Selection of training and the trainees}

Training is chosen on the basis of the following factors.

(a) Individual training needs (assessed upon commencement and at the annual performance review). This is achieved through performance reviews which are undertaken annually, usually in the spring. At the reviews, training is discussed with individuals. Department heads are responsible for providing to the HR director a list of all training identified with individuals at review time for incorporation into the company training planning process.

(b) Ongoing requirements, for example, for health and safety purposes, renewal upon expiry of certificates. Training is assessed at the time of induction for new starters. As a matter of urgency regarding health and safety training and then for integration into the training planning process.

(c) Changes in legislation, client requirements, etc.

(d) The needs of the business/business improvement activities; for example, new software. The company's annual training plan is drawn up in July/August for submission to ConstructionSkills for purposes of Grant B funding. The company has been using this route to training for some years as they are now able to claim funding for a full range of management, administration and IT training across all 
employee groups. Training is also chosen based on any business improvement targets or aims. The company embarked upon a series of customer care training days for all their key suppliers, their employees and clients.

\subsection{Types of training}

5.5.1. Construction skill certification scheme (CSCS). This scheme shows the proof of the level of competence in a company by raising the standard of health and safety, providing a highquality workforce with a recognised skills, competences and qualifications. The company ensures that all the relevant employees (i.e. excluding accounts, personnel and administration staff) are in possession of a CSCS card, or are currently working towards achievement of an NVQ qualification in order to qualify for one. In this case, the company was awarded the Gold Certificate of Achievement by CSCS in January 2008 to recognise $89 \%$ of employees are certified. The employees are motivated for this scheme because of recognition of skills, competences and qualifications. It also helps the employer in job commissioning as evidence of promotion of greater health and safety, personnel training awareness and confidence by clients.

\subsubsection{Investor in People - Team Building and Business} Improvement Training Days. The investors in people (IiP) standard was instituted in 1990 to help firms adopt best practice in integrating training and human resource development with business performance objectives. Since 2001 the case company has been holding team-building and business improvement days for office and construction staff. The focus was to improve both their soft and technical skills in the area of IT, business and financial management, and customer relations.

\subsubsection{Considerate constructors scheme (CCS). This scheme} outlaws unsafe and untidy construction sites and improves the image of the industry by improving the standard of site management and the behaviour of site operatives. All the company's site follows CCS guidelines and abides by the CCS special codes. The training on how to show respect for people who live and work near sites is delivered through many different routes. For example, during the designing and managing of work process, Business Improvement Days which are held twice a year, supply chain conference, etc.

5.5.4. Supply chain conference. This conference was organised by the company and attended by representatives from 30 subcontracting firms. The conference was aimed at the following activities.

(a) Sharing best practice skills through indirect training of all the subcontracting firms.

(b) Promoting the image of the company in order to retain all the members of the chain due to stiff competition in the market.

(c) Presenting an elaborate future strategic plan to the supply chain members.

(d) Discussing the business standards as well as raise the awareness about recent developments both in policy and practices in the industry.

For instance, the company's key performance indicators were presented. The issues of the Pre-Qualification Requirements for the subcontractors were discussed. A lecture about soft issues in the industry was given, for example, on the importance of CSCS card, the construction skills of the subcontractor's staff and making sure that all their workers pass the Criminal Records Bureau checks. The company also called for conduct and appearance improvement, which will impress their clients with regards to their professionalism. Regarding the quality control issues a group discussion about the procedure and checkpoint in quality control was arranged. The company agreed to provide each subcontractor with quality control specification afterwards. The conference also discussed safety and sustainability issues.

5.5.5. Other schemes to help young people. The company is involved in the Future Build Scheme, which is an initiative to assist unemployed youngsters enter the building industry. A good example is Youth Works and Positive Futures - this scheme helps under-achieving youngsters gain work experience and employment with local businesses. One place has been offered this year. This youngster has been attending college in the evenings. The company helped him with transport and provision of tools and he remains employed with them.

5.5.6. Curriculum enhancement. The company has worked with schools as part of the curriculum enhancement scheme run by the Construction Industry Training Board (CITB). This scheme is aimed at encouraging more youngsters to take up construction as a career and educate them as to the wide variety of jobs available in the industry.

5.5.7. Work experience. The company provided at least three work placements per annum, both to schools in the local area and also for unemployed people who need to gain site experience. Figure 7 presents skill competency building by the contracting firm. The competency building is focused on the internal workforce and external supply chain members, with their integral internal and external funding mechanisms and types of training they offered. The overarching aim is to train/educate both the internal and external (supply chain) through knowledge sharing and learning in order to fill the skills gaps or create a new workforce. Some types of training by internal workforce and external supply chain member are highlighted in the figure, such as CSCS, OSAT, technical and soft skills, etc. These activities are carried out with internal and external funding mechanisms.

\subsection{Benefits and achievements from investment in training to the company}

The company believes that there are inextricable links between the level of investment in training and the fortunes of the company in terms of turnover and profitability. The turnover and profit rose from $£ 10$ million in 2002 to $£ 32 \mathrm{~m}$ in 2007. In the same vein, the profit rose from $£ 102000$ in 2002 to over $£ 1$ million in 2007. This link is supported from the human capital perspective where training is seen as an investment that increases worker productivity. A number of merits have been derived by the case company in training its workforce: less job mobility, higher productivity, improvement in key performance indicators (KPIs), increase in organisational commitment by the workforce and high retention rate.

5.6.1. Information technology. It was revealed that in 2000 only a handful of staff used computers. A comprehensive programme of IT training and software implementation has taken 


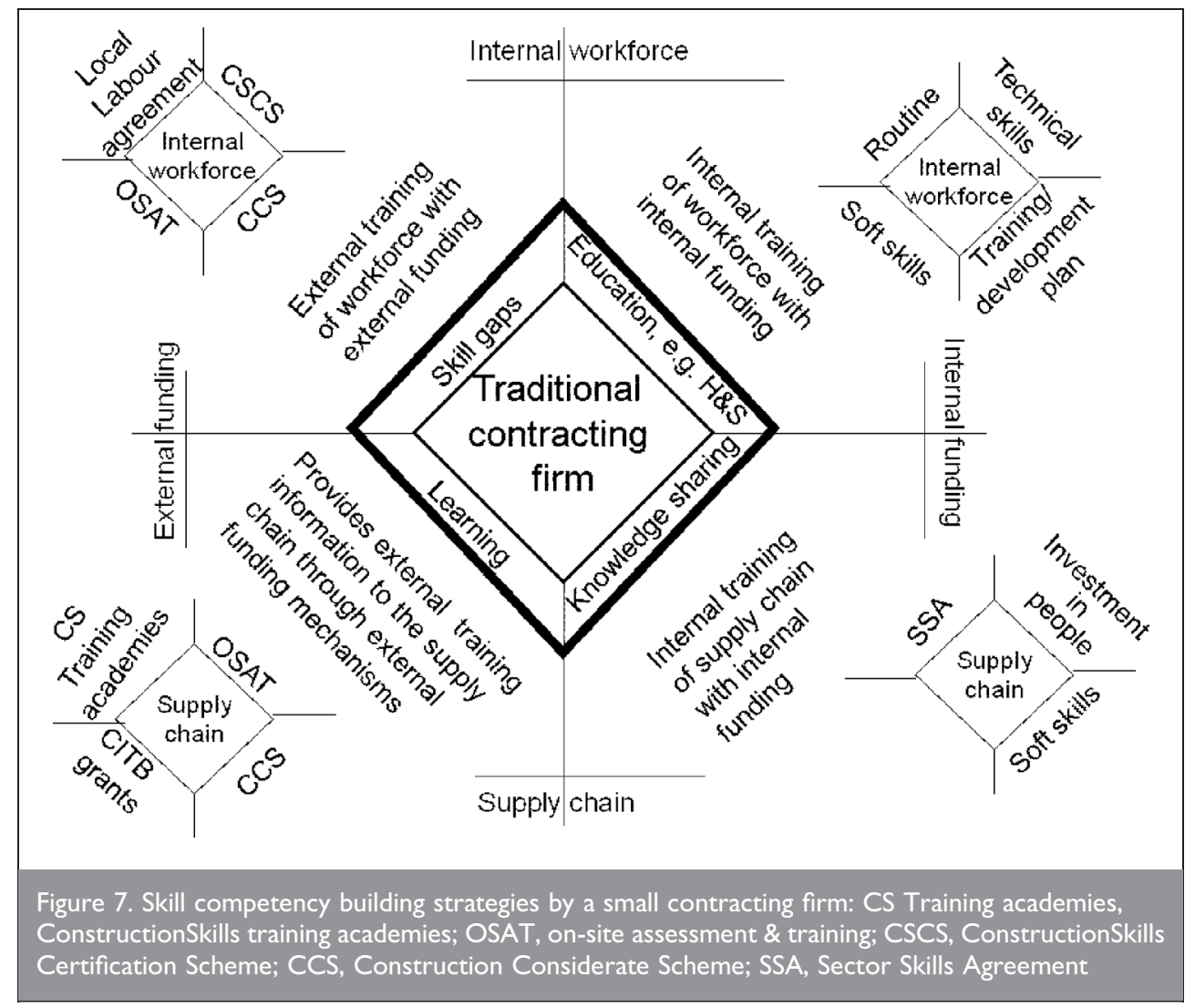

teambuilding and training it has been short-listed for the 'Best Places to Work in Construction in 2007 and 2008'.

\section{CONCLUSIONS}

Long-term workforce retention and continuous training through realistic strategic planning should be of the primary importance for all the companies. This will allow a long-term industry training plan that promotes the training of staff during different economic periods and eliminates cyclical market effects to reaching crisis levels. The case company has successfully been involved in a series of projects under government training initiatives and specific training driven by company's needs.

The case company has shown the importance placed on

place since 2000 to assist the business to adopt up-to-date business processes. All office staff as well as site managers and site supervisors are fully trained in appropriate IT systems and equipped with lap-tops for site administration and quality purposes.

5.6.2. Partnering. The company document revealed that as soon as it was short-listed for its first 'partnered' project in 2001 the company invested in partnering training for the director responsible. The company has taken part in two long-term partnering frameworks and undertaken many other single-project partnering schemes, in the public sector, namely

(a) 37 projects in total

(b) $58 \%$ of turnover (in the past 3 years).

5.6.3. Communication, education and teamwork. Two Business Improvement Days are held annually, for site and joiner's shop employees and for staff. These are designed to:

(a) involve employees in formulating the business objectives for the year

(b) bring employees up-to-date on industry initiatives

(c) review KPIs

(d) promote teamwork

(e) review CCS performance

(f) identify business improvements

(g) solve problems

(h) transfer knowledge/understanding via departmental and project team presentations.

5.6.4 Bi-annual business plan updates. This is held in March and August for all staff, reporting on all the above and achievements against company and departmental targets. As a result of the company's improved concentration on communication, young people, which enabled the company to recruit young people under different schemes from the project locality. The young are encouraged to remain in the industry by offering several types of assistance and clear career progression as demonstrated by the case company. Therefore efforts should not be relented in retaining and training the workforce and improving the industry's image. This will place the industry in a position to respond to a sudden upturn in the market.

The contractors should be aware of construction skills grants and funds for training. The CITB-ConstructionSkills grants are available to support a wide variety of training within the industry, covering key initiatives such as qualifying existing workers, improving health and safety, and training new recruits. The contracting firms should also organise a forum where such information can be passed onto the subcontractors. This was effectively demonstrated by the case company by organizing a supply chain conference.

An effective training plan is important because of the diversity of construction training requirements, management of the workforce and for subcontractors in obtaining funding. Funding has been one of the major obstacles in training especially for SMEs. SMEs need a training and development plan to be prepared and submitted on time. Firms can claim grants for training in many disciplines that benefit their business - this is not limited only to construction-based programmes but also includes computer skills, accountancy and administration as demonstrated by the case company.

\section{REFERENCES}

1. OfFice OF Government Commerce. 2005-2015 Construction Demand/capacity Study, Full Report. Deloitte, Office of Government Commerce, 2006. 
2. Construction Industry Training Board. Technological Change and Construction Skills in the 1990s. Construction Industry, Training Board, Bircham Newton, 1999, Research document.

3. DRUCKer J. and White G. Managing People in Construction. Institute of Personnel and Development, London, 1996, pp. 107-111.

Q5 4. Thomas J. C. Direct action. Building, 1999, 3 May, 36-38.

5. Gruneberg S. L. Construction Economics - An Introduction. Macmillan, London, 1997.

6. BцYтH A. Hard labor - the drive for new blood http:// www.rics.org/Knowledgezone/Journalsandmagazines/ RICSBusiness/lab_020207.html. Accessed: January 2008.

7. Mackenzie S., Kilpatrick A. R. and AKintoYe A. UK construction skills shortage response strategies and an analysis of industry perceptions. Construction Management and Economics, 2000, 18, 853-862.

8. OfFice of GovernMent COMMERCE. Increasing Competition and Improving Long-term Capacity Planning in the Government Market Place (Kelly report). Office of Government

Q4 Commerce, 2003.

9. Construction Skills. Sector skill agreement, http:// www.constructionskills.net/sectorskillsagreement/. Accessed: October 2008.

10. Huemann M., Keegan A. and Turner J. R. Human resource management in the project-oriented company: a review. International Journal of Project Management, 2007, 25, 315-323.

11. Gann D. and SenKer P. Construction skills training for the next millennium. Construction Management and Economics, 1998, 16, 569-580.

12. Agapiou A. A review of recent development in construction operative training in the UK. Construction Management and Economics, 1998, 16, 511-520.

13. SteVens M. Human capital theory and UK locational training policy. Oxford Review of Economic Policy, 1999, 15, No. 1, 16-32.

14. GRUGULIS I. The contribution of national vocational qualifications to the growth of skills in the UK. British Journal of Industrial Relations, 2003, 41, No. 3, 457-475.

15. Gospel H. The decline of apprenticeship training in Britain. Industrial Relation Journal, 1995, 26, No. 1, 32-44.

16. SIEBEN I. Does training trigger turnover - or not? The impact of formal training on graduates' job search behaviour. Work, Employment \&t Society, 2007, 21, No. 3, 397-416.

17. Clarke L. and Wall C. UK construction skills in the context of European development. Construction Management and

18. GoSPEL H. The modern apprenticeship: new wine in old bottles? Human Resources Management Journal, 1998, 8, No. 1, 5-22.

19. Edum-Fotwe F. and McCafFer R. Developing project management competency: perspective from the construction industry. International Journal of Project Management, 2000, 18, No. 2,111-124.

20. Crawford L., Moris P., Thomas J. and Winter M. Practitioner development: From trained technicians to reflective practitioners. International Journal of Project Management, 2006, 24, 722-733.

21. WINCH G. The growth of self-employment in British construction. Construction Management and Economics, 1998, 16, 531-542.

22. PANT I. and BARoudi B. Project management education: The human skills imperative. International Journal of Project Management, 2008, 26, 124-128.

23. Muzio E., Fisher D. J., Thomas E. R. and Peters V. Soft skills quantification (SSQ) for project manager competencies. Project Management Journal, 2007, 38, No. 2, 30-38.

24. MeLIK R. The rise of the project workforce. Project Management Journal, 2007, 38, No. 4, 70.

25. Abdel-Wahab M. S., Dainty A. R. J., Ison S. G., Bowen P. and HAZLEHURST G. Trends of skills and productivity in the UK construction industry. Engineering, Construction and Architectural Management, 2008, 15 No. 4, 372-382.

26. Pheng L. S. and ChuAN Q. T. Environmental factors and work performance of project managers in the construction industry. International Journal of Project Management, 2006, 24, 24-37.

27. Lово Y. B. and WiLKINSON S. N. New approaches to solving the skills shortages in the New Zealand construction industry. Engineering, Construction and Architectural Management, 2008, 15, No. 1, 42-53.

28. Office for National Statistics. Construction Statistics Annual. Palgrave Macmillan, 2008.

29. OfFice of Government Commerce. Is bigger always better aggregation. Office of Government Commerce, 2001.

30. CoX A. and IreLAND P. Managing construction supply chains: the common sense approach. Engineering Construction and Architectural Management, 2002, 9, Nos. 5/6, 409-418.

31. Department of Trade and Industry. The Construction Statistics Annual 2006 Edition. TSO Publishing.

32. Morton R. and JAgGer D. Design and the Economics of Building. E \& FN Spon, London, 1995.

33. Constructon Skills Report. The Blueprint for UK Construction Skill 2006-2010. ConstructionSkills, 2006.

34. Chartered Institute of Building. Skills Shortages in the UK Construction Industry. CIOB, 2006.

35. RuIZ Y. Skills Shortages in Skilled Construction and Metal Trade Occupations, Labor Market Trends. National Statistics Feature, 2004.

\section{What do you think?}

To comment on this paper, please email up to 500 words to the editor at journals@ice.org.uk

Proceedings journals rely entirely on contributions sent in by civil engineers and related professionals, academics and students. Papers should be 2000-5000 words long, with adequate illustrations and references. Please visit www.thomastelford.com/journals for author guidelines and further details. 